\title{
Productivity growth on Finnish grain farms from 1976-2006
}

\author{
Viljatilojen tuottavuuskehitys Suomessa vuosina 1976-2006
}

\author{
Sami Myyrä ${ }^{1}$, Pekka Pihamaa $^{2}$ ja Timo Sipiläinen ${ }^{1}$ \\ ${ }^{1}$ MTT Taloustutkimus, Luutnantintie 13,FI-00410 Helsinki, etunimi.sukunimi@mtt.fi. \\ ${ }^{2}$ Maa- ja metsätalousministeriö, etunimi.sukunimi@mmm.fi.
}

Maatalouden tuottavuus ja erityisesti tuottavuuden nousu ovat välttämättömiä edellytyksiä suomalaisten maatilojen ja elintarviketeollisuuden selviytymiselle. Epäsuotuisat olosuhteet ja pieni tilakoko ovat jo sinänsä haasteita, mutta tuottavuuskehityshaaste on entisestään koventunut, kun tuet on irrotettu tuotannosta. Lisäksi viljelijöiden kannusteet tuottavuuskehityksen nopeuttamiseen ovat olennaisesti heikentyneet pellon omistusrakenteessa tapahtuneen muutoksen myötä. Vuonna 2004 vain puolet peltoalasta oli viljelijöiden omistuksessa.

Tutkimuksessa tarkasteltiin pitkän aikasarja-aineiston avulla suomalaisten viljatilojen tuottavuuskehitystä. Aineistoa hyödynnettiin tehokkaasti, sillä siihen sovellettiin erilaisia menetelmiä. Menetelmien puitteissa pystyttiin arvioimaan sekä tuottavuuden vuotuista vaihtelua sekä pidemmän aikavälin trendejä. Myös tuottavuuskehityksen osatekijöitä pystyttiin tarkastelemaan erikseen.

Suomalaisten viljatilojen tuottavuuskehitys johtuu pitkälti teknologisesta kehityksestä. Tutkimuksen mukaan skaalavaikutukset, eli suurtuotannon edut, ovat tarkasteluvälillä vaikuttaneet hyvin vähän tuottavuuskehitykseen, ja lisäksi niiden vaikutus on ollut ajan myötä jopa laskeva.

Vuosina 1976-2006 viljatilojen tuottavuus nousi mittaustavasta riippuen keskimäärin 0,6-1,7 \% vuodessa. Keskimääräinen vuotuinen tuottavuuskehitys oli kuitenkin niin pieni, että kokonaiskehitys koko tarkastelujaksolla oli samansuuruinen kuin suurimmat vuotuiset vaihtelut. Verrattaessa havaittua tuottavuuskehitystä esimerkiksi kevätviljojen satopotentiaalin kehitykseen $(0,13-0,17 \%$ vuodessa) voidaan todeta tuottavuuskehityksen olevan useiden osatekijöiden summa. Teknologisen kehityksen myötä suomalaisten kuluttama viljamäärä pystytään tuottamaan nyt huomattavasti pienemmällä työmäärällä kun vielä 1970 luvun puolivälissä. Tulokset osoittavat kuitenkin sen, että yksittäiset vuodet voivat poiketa huomattavastikin pitkän aikavälin kehitystrendistä.

Tulos osoittaa viljanviljelyn tuottavuuden olevan sidoksissa vuosittain vaihteleviin sääolosuhteisiin. Tämä haastaa tutkimusmenetelmät, joiden pitäisi toisaalta osoittaa hidas taustalla oleva tuottavuuskehitys ja samalla suuri vuotuinen vaihtelu tuottavuuden tasossa. Lyhyisiin aikasarjoihin perustuvat tarkastelut eivät tulosten perusteella palvele maatalouspolitiikan suunnittelua kovinkaan hyvin.

Key-words: technical change, scale effect, production function, time trend, general index. 


\section{Introduction}

Profitability at the farm level is determined by prices, subsidies and the productivity at which inputs are transformed to outputs. Prices and subsidies are to a large extent exogenous for farmers. However, farmers are able to adjust productivity at the farm level. This takes place according to the incentives given in prices and subsidies. One could say that increased productivity is the farmer's contribution to the future success of Finnish agriculture.

The problem in Finland is that productivity has remained low and productivity growth has stagnated for several reasons. First, productivity has been low because of the natural handicap resulting from the unfavourable climate and the small size of farms. Second, the political tendency of decoupling market-distorting price supports and transforming them into direct income payments has challenged farmers to reach the productivity goals of the CAP under Nordic production conditions. Third, farmers' incentives are also limited by some institutional settings that substantially cut incentives to improve productivity. Land tenure insecurity is one of the most important of these institutional questions.

Institutions also have an influence on farmers' incentives for productivity improvements. Despite the rapid decline in the number of active farmers, the number of farmland owners has not decreased at a similar rate, since many former farmers and their successors have kept the land in their ownership but leased it out to active farmers. Farming under the insecurity of land tenure caused by land leasing in strongly regulated land lease markets has, however, led to the neglect of land improvements.

This study has three main goals. The first goal is to determine the rate of productivity growth on Finnish grain farms over the 30-year period from 1976 to 2006. We apply both time trend and general index techniques in order to capture the patterns of technical change during the period. The second goal is to examine how technical change has evolved in different subsidy regions and in different size classes of grain farms. The third goal is to clarify the role of the scale effect in productivity growth in general and especially in various farm size classes, but also in different subsidy regions.

\section{The econometric model}

In the case of a logarithmic production function, following Denny et al. (1981) and Bauer (1990), the Divisia index of total factor productivity (TFP) growth can be defined as the growth in scalar output (y $=\mathrm{f}(\mathrm{x}, \mathrm{t} ; \alpha)$ ), which cannot be explained by the growth in the input quantity index (vector $\mathrm{X}$ ) over time $(\mathrm{t})$ :

$$
\operatorname{TFP}=\dot{y}-\dot{X} \text { when } \dot{X}=\sum_{j} \frac{w_{j} x_{j}}{C} \dot{x}_{j}
$$

where $\frac{w_{j} X_{j}}{C}$ is the observed cost share on the input $\mathrm{j}(\mathrm{w}$ is the price of the input $\mathrm{x}$ ) and the dot indicates the rate of change. In a single output case, with constant returns to scale (CRS) and cost efficiency (CE), TFP growth equals technical change (TC). In our analysis, we assume efficiency but allow non-constant returns to scale. Thus, our production function is not a frontier function but an average production function, and technical change is measured in relation to the shifts in this average function.

Taking the total differential of logarithmic $\mathrm{y}=\mathrm{f}(\mathrm{x}, \mathrm{t} ; \alpha)$ and adding it into (1) we obtain:

$$
\begin{aligned}
\operatorname{TFP} & =\partial \ln y / \partial t+\sum_{j}\left(\varepsilon_{j}-\frac{w_{j} x_{j}}{C}\right) \dot{x}_{j} \\
& =\partial \ln y / \partial t+\left(\sum_{j} \varepsilon_{j}-1\right) \sum_{j}\left(\frac{\varepsilon_{j}}{\sum_{j} \varepsilon_{j}}\right) \dot{x}_{j}+\sum_{j}\left[\left(\frac{\varepsilon_{j}}{\sum_{j} \varepsilon_{j}}\right)-\frac{w_{j} x_{j}}{C}\right] \dot{x}_{j}
\end{aligned}
$$


where $\varepsilon_{j}$ is the elasticity of the output with respect to input j, i.e. $\varepsilon_{j}=\partial f(x, t ; \alpha) / \partial \ln x_{j}$, when a logarithmic function is applied. $\sum_{j} \varepsilon_{j}$ is the sum of output elasticities of inputs, indicating returns to scale. When the sum is larger than one, returns to scale are increasing. A sum of one indicates constant returns to scale, and a sum less than one suggests that returns to scale are decreasing.

If we assume allocative efficiency of production, ${ }^{1}$ we may drop the last part of equation 2 , since the elasticity share and cost share must coincide. From this it follows that we only have two components left that can be derived from the production function: technical change and the scale effect on productivity growth. If production technology is time-invariant, no technical change occurs $(\partial \ln y / \partial t=0)$. On the other hand, if CRS prevails, the scale component does not contribute to productivity growth (see Kumbhakar and Lovell 2000). For this technical decomposition, no detailed price information is needed, although we often have to assume that farmers face equal prices in order to be able to estimate changes in TFP. ${ }^{2}$ The main challenge is thus to estimate a suitable production function.

\section{Time trend and general index models}

In our analysis, we apply two different models to capture technical change. In the time trend model (TT), the trend variable is used as a regressor along with the input variables. It is a proxy variable representing the rate of technical change or the shift in the production function over time, and produces smooth technological changes. As a starting point, we allow a flexible translog functional form with non-neutral technical change and heterogeneous changes between size classes of farms. ${ }^{3}$ The time trend (TT1) model can be written as:

$$
\ln y=\alpha_{0}+\sum_{j} \alpha_{j} \ln x_{j}+\alpha_{t} t+1 / 2 \sum_{j} \sum_{k} \alpha_{j k} \ln x_{j} \ln x_{k}+1 / 2 \alpha_{t t} t^{2}+\sum_{j} \alpha_{j t} \ln x_{j} t+v,
$$

where $\mathrm{v}$ is the random noise term. The production function above is assumed to satisfy symmetry conditions; the regularity conditions can be tested.

The price of smoothness in the measures of technical change in the TT model is that cyclical phenomena and short-term changes in productivity or its components could not be revealed. This feature of the TT model is referred to as the "time-trend straitjacket" in Kumbhakar et al. (1999)

In the general index model of Baltagi and Griffin (1988), the trend variable $t$ is replaced by a vector of dummy time variables, where $A(t)(t=1, \ldots, T)$ are parameters to be estimated. The time trend model results in a smooth shift in the production function over time, while time dummies capture erratic changes over time. The latter model is thus less restrictive and preferable when capturing the variation in grain production in Finland. The yields are quite volatile, due to the climatic conditions. In this case we also allow non-neutral technical change. ${ }^{4}$ Thus, the general index (GI) model of the production function can be written as:

$$
\ln y=\alpha_{0}+\sum_{j} \alpha_{j} \ln x_{j}+1 / 2 \sum_{j} \sum_{k} \alpha_{j k} \ln x_{j} \ln x_{k}+\sum_{j} \alpha_{j t} \ln x_{j} t+A(t)+v
$$

Technical change (TC) (derivatives with respect to time) in the time trend and general index models can be expressed as:

$$
T C_{T T 1}=\alpha_{t}+\alpha_{t t} t+\sum_{j} \alpha_{j t} \ln x_{j} \text { and }
$$

\footnotetext{
${ }^{1}$ We do not necessarily assume technically efficient production. The minimum assumption of our analysis is that technical inefficiency, if it occurs, must be time invariant.

${ }^{2}$ Many of the inputs are only recorded in monetary terms. Farm-specific input prices are not available. Thus, sector level price indices have to be applied for the derivation of implicit quantities.

${ }^{3}$ This heterogeneity is modelled by allowing different slope parameters on time according to the farm size class.

${ }^{4}$ In this case we allow heterogeneity of technical change by introducing separate dummies for the farm size classes.
} 


$$
T C_{G I 1}=\left(A_{t}-A_{t-1}\right)+\sum_{j} \alpha_{j t} \ln x_{j}
$$

In the flexible translog production function, technical change is clearly not independent of the point at which it is calculated when continuous $t$ is applied. This leads us to use the geometric mean between $t$ and $\mathrm{t}+1$ (Coelli et al. 1998).

As we have shown earlier, TFP growth can be expressed as a sum of technical change and the scale effect

$$
\begin{aligned}
& \dot{T F P}=T C+(R T S-1) \sum_{j} \frac{\varepsilon_{j}}{R T S} \dot{x}_{j}, \text { where } \\
& \varepsilon_{j}=\frac{\partial \ln y}{\partial \ln x_{j}}=\alpha_{j}+\alpha_{j j} \ln x_{j}+\sum_{k} \alpha_{j k} \ln x_{k}+\alpha_{j t} t \text { and } R T S=\sum_{j} \varepsilon_{j} .
\end{aligned}
$$

As in the case of technical change, the effect of returns to scale is not independent of the point at which the outcome is calculated. Therefore, we apply a similar approach to that with technical change and determine the scale effect (SE) by average elasticities for sequential periods.

\section{The data}

The data were collected from Finnish bookkeeping farms, which are also included in the EU Farm Accountancy Data Network (FADN) for Finland. This study focuses on grain farms. We used the following definition to further classify the farms in the data: over a period of three years an average of at least $65 \%$ of annual agricultural turnover (without subsidies) must have been derived from the sale

\begin{tabular}{|c|c|c|c|c|c|c|c|c|c|c|c|}
\hline \multirow[t]{2}{*}{ Year } & \multicolumn{3}{|c|}{ Hectares } & \multicolumn{2}{|c|}{$\begin{array}{l}\text { Market return } \\
\text { (€/year) }\end{array}$} & \multicolumn{2}{|c|}{$\begin{array}{c}\text { Labour } \\
\text { (hour/year) }\end{array}$} & \multicolumn{2}{|c|}{$\begin{array}{l}\text { Capital } \\
(€ / \text { farm) }\end{array}$} & \multicolumn{2}{|c|}{$\begin{array}{c}\text { Costs } \\
\text { (€/year) }\end{array}$} \\
\hline & $\mathbf{N}$ & Mean & Std & Mean & Std & Mean & Std & Mean & Std & Mean & Std \\
\hline 1976 & 72 & 37.70 & 21.00 & 17901 & 12345 & 1812 & 904 & 213026 & 122206 & 20691 & 13924 \\
\hline 1986 & 127 & 36.59 & 19.57 & 16934 & 10969 & 1517 & 792 & 247996 & 153696 & 24273 & 13693 \\
\hline 1996 & 85 & 49.57 & 23.59 & 20619 & 11036 & 1473 & 764 & 264937 & 137829 & 25374 & 12007 \\
\hline 2006 & 95 & 56.44 & 31.71 & 23855 & 18477 & 996 & 637 & 248869 & 162549 & 24832 & 17116 \\
\hline
\end{tabular}
of small grains (wheat, rye, barley, oats and turnip rape) during the research period (Table 1).

Table 1. Main statistics at ten-year intervals.

\section{Results}

When functional form of the production function was tested it turned out that the Cobb-Douglas without time components is not sufficient to describe the relationship between the output and inputs. Thus, significant technical change occurs over time $(p<0.001)$. Technical change also differs statistically significantly between farm size classes $(p<0.001)$. Cross terms of inputs and their second order terms are significant at the $0.5 \%$ risk level. In addition, although the first derivatives of all inputs are positive (monotonicity is satisfied), the production function including the above-mentioned terms violates the regularity condition for most of the data points, according to the principal minor test. Therefore, these terms have been removed from the model specification that the empirical results are based on. The final function form for the production function is logarithmic production function, which is not as flexible as translog, but more flexible than Cobb-Douglas. For this on we call this function as extended Cobb-Douglas.

\section{Elasticities and technical change}

Output elasticities with respect to variable inputs are calculated from $\varepsilon_{q}=\partial \ln y / \ln x_{j}$. The input elasticities vary over time but not across farms. These variations result from the use of an extended Cobb-Douglas function. Returns to scale are calculated from the sum of the input elasticities. 
The results indicate that output elasticities for labour are quite low. On average, elasticity for labour has been around $0.10-0.11$. Over the years the investments in buildings, machinery and land improvements have given a larger contribution to the output. Independent of the model, elasticities for capital were around $0.26-0.28$, and were found to be invariant over time.

The farm-specific estimates of returns to scale (RTS) are defined as the elasticity of output with regard to a proportionate change in all inputs. Sample means of returns to scale were 0.79 (TT) and 0.77 (GI). Means of RTS were found to be below one, indicating decreasing returns to scale at the average level. ${ }^{5}$

The results indicate no major differences in elasticities or returns to scale between subsidy areas. This also holds over the entire study period. There are cross-term parameters between time and input variables in production functions, which allow technical changes to be farm-specific.

Table 5. Means of input elasticities, returns to scale and technical change.

\begin{tabular}{|c|c|c|c|c|}
\hline \multirow[b]{2}{*}{$\begin{array}{l}\text { Model / farm size } \\
\text { /subsidy area }\end{array}$} & \multicolumn{3}{|c|}{ Elasticities } & \multirow[b]{2}{*}{ RTS } \\
\hline & Labour & Capital & $\begin{array}{c}\text { Variable } \\
\text { cost }\end{array}$ & \\
\hline Time trend (TT) & 0.106 & 0.282 & 0.403 & 0.791 \\
\hline General index (GI) & 0.098 & 0.264 & 0.406 & 0.768 \\
\hline \multicolumn{5}{|c|}{ Technical change } \\
\hline & \multicolumn{2}{|c|}{ TT } & \multicolumn{2}{|c|}{ GI } \\
\hline very small & \multicolumn{2}{|c|}{0.010} & \multicolumn{2}{|c|}{-0.001} \\
\hline small & \multicolumn{2}{|c|}{0.013} & \multicolumn{2}{|c|}{0.009} \\
\hline medium & \multicolumn{2}{|c|}{0.017} & \multicolumn{2}{|c|}{0.012} \\
\hline large & \multicolumn{2}{|c|}{0.021} & \multicolumn{2}{|c|}{0.015} \\
\hline very large & \multicolumn{2}{|c|}{0.023} & \multicolumn{2}{|c|}{0.019} \\
\hline A & \multicolumn{2}{|c|}{0.018} & \multicolumn{2}{|c|}{0.007} \\
\hline B & \multicolumn{2}{|c|}{0.016} & \multicolumn{2}{|c|}{0.010} \\
\hline $\mathrm{C} 1-\mathrm{C} 4$ & \multicolumn{2}{|c|}{0.017} & \multicolumn{2}{|c|}{ NA } \\
\hline
\end{tabular}

The dummy variable indicating the policy regime change from national agricultural policy to the CAP was found negative and significant in the TT model. In the TT model, the shift of the production function is smooth. However, the rate of technical change slowed down after the mid-1990s, signalling the changes in production structure and agricultural policy.

The GI model captures the annual variation in the production function caused by changing weather conditions from year to year. The exceptional cropping years can be easily distinguished (Fig. 1). The large variation in technical change highlights the nature of crop farming in Finland. The change in productivity, which is mainly caused by technical change, is strongly related to the weather conditions. Based on these findings, we argue that it might be misleading to rely on statements of productivity changes in Finnish crop production based on short time series. One extension is that the production function estimated from a very short data set might give biased results, simply because of the weather conditions.

The general index reveals the annual variation in technical change. The overall mean of technical change was 0.011 (1.1\% per year) and the standard deviation was as large as 0.171 . This result indicates that is not easy to verify slow technical process if the production function typically shifts with a $95 \%$ confidence interval by $\pm 34 \%$ annually. Other industries do not suffer from similar fluctuation, but there are numerous examples of the connection between technical change in grain production and the weather.

\footnotetext{
${ }^{5}$ The results based the standard OLS model suggest that returns to scale are close to constant. This indicates that productivity levels differ between farms, but when this difference is taken into account, returns to scale do not support productivity growth with increasing size of the farm.
} 


\section{Total factor productivity growth}

Total factor productivity (TFP) increased by $0.6 \%$ per year in the GI model and $1.7 \%$ per year in the TT model. However, the resulting change in TFP in the TT model over the study period was at the same level than the highest yearly changes in TFP measured by the GI model. The results for the annual changes in total factor productivity are presented in Figure 1.
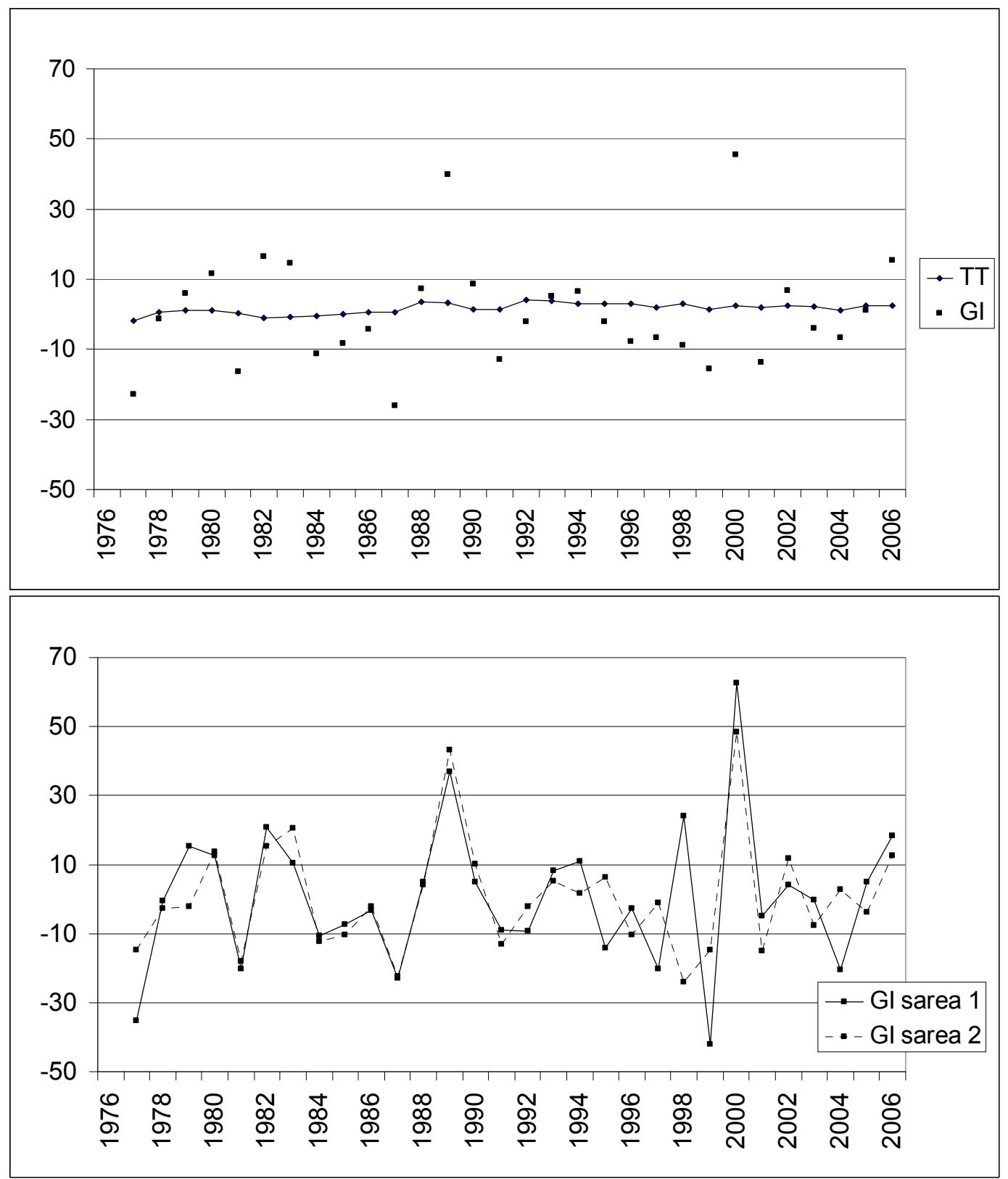

Figure. 1. Annual change in total factor productivity. TT $=$ Time trend. GI $=$ General index. Sarea 1 refers to subsidy area A and sarea 2 to subsidy area B.

Figure 1 illustrates the idea of using two separate models. The annual variation in TFP is large and captured by the general index model, because this model allows more flexibility with respect to yearto-year changes in productivity. However, it might be impossible to capture the general trend in TFP based only on general index model results. This issue was topical during the first years of EU membership, when the CAP was implemented in Finland. As Figure 1 illustrates, the cropping year 1994 was above the average. However, during the following years from 1995 to 1999, the first under the CAP, weather conditions were poor and TFP collapsed. At that time, it would have been 
impossible to say anything about the contribution of the policy regime change to the productivity of grain farming in Finland only based on the general index model. Thus, we used in our time trend model a CAP dummy that allows the time trend to differ before and after the EU accession. Estimation results give empirical justification that the CAP has hindered the increase in the productivity of grain farming in Finland. However, the size of the effect is extremely small.

The productivity trends of different subsidy areas were also examined, as we found that production functions differed between subsidy areas. Thus, the data were divided according to subsidy area and the same models were applied for each region. The trends in total factor productivity are presented in the lower parts of Figure 2. The results indicate that productivity trends for the most part follow the same pattern. ${ }^{6}$ Some exceptional years were 1995, 1997, 1998 and 2004, all which were under the CAP.

\section{Conclusions}

The results suggest that in agriculture, and especially in grain farming, it is difficult to evaluate, for example, the short term effects of policies on technical change. The results indicate that it might be misleading to rely on reports concerning productivity changes in Finnish crop production that are based on short time series. The selection of the first research year is also always a problem in the analysis of productivity changes in crop production. We addressed these challenges by taking a long (30 years) time series of data for Finnish grain farms, in which were helped by the reliable and wellestablished Finnish bookkeeping system. Based on our experience, the time trend model is not flexible enough to capture the annual variation in Finnish grain farming, and in this sense results gained from the general index model are preferable. Baltagi and Griffin (1988) also preferred the GI model, since it closely follows the changes in Divisia indices. Kumbhakar et al. (1999), however, presented some contradictory views on the TT model.

The productivity of Finnish grain farming has increased over the long term. However, this development has not been rapid enough to cover unfavourable development in the output-input price relation and sustain the profitability of grain farms. In the triune of farm profitability, including prices, subsidies and productivity, it is not productivity that has broken down, even though this has been a very popular topic in the media. However, a more rapid increase in productivity would have helped in achieving profitability goals. The decreasing effects from the recent policy changes, namely the introduction of the CAP, on TFP are worrying with respect to the future of Finnish grain farming.

\section{References}

Baltagi, B.H. \& Griffin, J.M. 1988. A general index of technical change. Journal of Political Economy 96: 20-41.

Bauer, B.W. 1990 Decomposing TFP growth in the presence of cost inefficiency, non-constant returns to scale, and technological progress. Journal of Productivity Analysis. 1: 287-299.

Coell, T.J., Rao P.D.S. and Battese, G.E. 1998. An Introduction on Efficiency and Productivity Analysis. Kluwer Academic Publishers. 275 p.

Denny, M., Fuss, M. and Waverman, L. 1981. The measurement and interpretation of total factor productivity in regulated industries with an application to Canadian telecommunications. In: Cowing, T.G. and Stevenson, R.E. (eds.) Productivity measurement in regulated industries. New York. Academic Press. p. 179-218.

FADN, Farm Account Data Network. Available on the Internet: https://portal.mtt.fi/portal/page/portal/www en/

Research/Economics/Business\%20Accounting. Cited Marsh 2009. Updated Marsh 2009

Kumbhakar S. C. \& Lovell C. A. 2000. Stochastic Frontier Analysis. Cambridge University Press.

Kumbhakar S.C.. Heshmati A. \& Hjalmarsson L. 1999. Parametric Approaches to Productivity Measurement: A Comparison among Alternative Models. Scandinavian Journal of Economics 101: 405-424.

\footnotetext{
${ }^{6}$ The number of observations was insufficient for regional estimation of the GI model in subsidy area 3.
} 